\title{
SPA SUCCESSES AND CHALLENGES IN TRANSDANUBIA, HUNGARY - RESULTS OF A SURVEY IN THREE SPA TOWNS
}

Zsuzsanna BACSI, PhD, associate professor

University of Pannonia, Georgikon Faculty

Address: $\quad$ H-8360 Keszthely, Deák F. u. 16

Phone: $\quad+36-83-545-366$

E-mail: $\quad$ h5519bac@ella.hu

Ernő KOVÁCS, PhD, associate professor

University of Pannonia, Georgikon Faculty

Address: $\quad$ H-8360 Keszthely, Deák F. u. 16

Phone: $\quad+36-83-545-120$

E-mail: $\quad$ h12725kov@ella.hu

Zsuzsanna LŐKE, PhD, assistant professor

University of Pannonia, Georgikon Faculty

Address: H-8360 Keszthely, Deák F. u. 16

Phone: +36-83-545-162

E-mail: loke@georgikon.hu

Acknowledgement: The research presented in the paper has been co-financed by the European Union through the Hungary-Croatia IPA Cross-Border Cooperation Programme. Project no: HUHR/0901/2.1.3., Project title: The role of health tourism in improving the competitiveness of rural regions in Hungary and Croatia. 


\title{
SPA SUCCESSES AND CHALLENGES IN TRANSDANUBIA, HUNGARY - RESULTS OF A SURVEY IN THREE SPA TOWNS
}

\begin{abstract}
Health tourism is one of the main development areas of tourism in Hungary. Health tourism development projects may initiate orders to the construction industry, preserve jobs, create new value and new jobs, and the multiplier effect may be beneficial for small and medium size enterprises in the surroundings of the investments. They can effectively contribute towards diminishing spatial and regional discrepancies, as thermal reservoirs are situated under $70 \%$ of the total land area of Hungary.

The paper presents the results of a survey carried out in 2010 in three spa towns in the western part of Hungary. The objective of the research was to identify the role of spa tourism in the competitiveness of the three Hungarian counties (Baranya, Somogy and Zala) of the Croatian-Hungarian border area. The survey was focused on the local population of the three towns, and on the visitors of the spas. The objective was to identify the key success factors of spa development, the level of tourist satisfaction, the impacts of the spa on the local community. The survey was a part of a large project that analysed the role of health tourism in improving the competitiveness of the Croatian - Hungarian border region.

The surveys were completed in August and September 2010, in three spa towns - Hévíz, Harkány and Nagyatád - on samples of 100 residents and 100 spa visitors, in each town.

Generally local residents showed a positive attitude towards the spa as an attraction for leisure and pleasure, appreciating bathing more than healing. They are rather satisfied with the spa services, but food and drinks, and fitness services are considered of lower quality. In Hévíz the spa prices were considered too high for value, and this is really the most expensive spa of the three. The local residents of Harkány complained about technical improvements needed, while the citizens of the small town Nagyatád were very satisfied with their spa.

In Nagyatád the spa was considered less important in the socioeconomic life of the town than in the other two famous spa towns. However, in Hévíz and Nagyatád the incomes earned and carreer prospects in the spa and related hotels were considered worse than the town average. The relationship between town leadership and spa were considered rather negative in Harkány. Local residents have positive feelings towards tourists, but the positive impacts of tourism are felt only in Hévíz, although here parking problems and high prices were felt as negative impacts. In Harkány the low number of tourists and the high prices were the main negative aspects, while in Nagyatád no negative impacts of tourism were felt.

The most marked differences in the visitors of the three spas are with respect to age, length of stay, the motivation and purpose of visit, the accommodation taken, the daily spending and cost of accommodation, and the opinions on the spa services. While the tipical visitor to Hévíz is elderly, near the pensioner age, and stays for about two weeks for a medical treatment, paying a high price for the accommodation, who is not completely satisfied with the services offered by the spa and by the town, the typical visitor to Harkány is rather similar, but spends much less on accommodation. The visitors to Nagyatád, however, are 3-4 years younger, spend only a little, often comes with a group in an organised tour, stays about half as long as the visitors of the other two spas, and is usually completely satisfied with the services of the spa and the town. Those visiting Nagyatád, have already been to several other spas, being experienced spa visitors. Nagyatád, unfortunately, seems to have difficulties in converting the favourable opinions into revenues, the visitors stay only for a short time, and spend very little, and the town is obviously capable to attract much less tourists than the other two - regionally or internationally renowned - spa resorts.

The survey results showed three different patterns for spa development: the pattern of an international success story of Hévíz, the situation of a regionally well known spa that has recently lost its attractiveness (Ha rkány) and the case of a small local spa in Nagyatád, that can successfully serve the local community, but lacks the preconditions needed to become a regional attraction.
\end{abstract}

Keywords: Spa, health tourism, tourist satisfaction, residents, survey, Transdanubia, Hungary

\section{INTRODUCTION}

Tourism is considered to be one of the most dynamically growing areas of the economy, both globally and in national scale. Its importance within the national economy of Hungary is demonstrated by its almost 6\% share in the GDP and nearly 9\% share in employment in 2009, without the multiplier effects (WTTC, 2002; MTZrt, 2002-2009). The natural endowments of 
the country, including excellent thermal resources, make it particularly suitable as a health tourism destination (Aquaprofit, 2007). Health tourism development projects - with due care - may initiate orders to the construction industry, preserve jobs, create new value and new jobs, and the multiplier effect may be beneficial for small and medium size enterprises in the surroundings of the investments. They can effectively contribute towards diminishing spatial and regional discrepancies, as thermal reservoirs are situated under $70 \%$ of the total land area of Hungary. The development of health tourism is justified by the fact, that this tourism type does not suffer from such strong seasonal fluctuations as leisure tourism in Hungary, it requires specially trained professional staff, and longer stay in the destination due to the predetermined duration of treatments. As demographic trends underline, the demand for health preservation and recuperation is expected to increase in the long run and Hungary has considerable comparative advantage in satisfying this demand, due to the richness and high temperature of its underground water resources (Kovács-Bacsi-Lőke, 2011b).

The present paper describes the partial research results of a large research project, which was to examine the conditions of success, in order to utilise the available resources for establishing, extending and modernising facilities in an economically viable and feasible way. The research was focused on the Croatian-Hungarian cross-border area, analysing the succcess of health tourism development projects in this area (Kovács-Bacsi-Lőke, 2011a).

\section{OBJECTIVES AND METHODS}

The objective of the research was to identify the role of spa tourism in the competitiveness of the three Hungarian counties (Baranya, Somogy and Zala) of the Croatian-Hungarian border area. As a part of a large research project (Kovács et al., 2011a), the currect research was based on primary data collected in the counties of Zala, Somogy ad Baranya countires. One spa resort was selected in each county, where local inhabitants and spa visitors were surveyed by questionnaires, about their views on the role of the spa and consumer satisfaction.

The primary questionnaire-based surveys and the interviews were aimed and identifying the impacts of health tourism developments on the settlement, the economic and social effects on the local population. The objectives were to identify the causes and preconditions of success for a spa development project that make a spa attractive for visitors, and to identify the factors that are most important for the spa visitors when making their travel decisions. Another aim was to see the impacts of the success or the failure of a spa on the incomes, 
employment situation, living conditions, and generally, the quality of life for the local community.

The surveys were completed in August and September 2010, in three spa towns - Hévíz, Harkány and Nagyatád - on samples of 100 residents and 100 spa visitors, in each town. The following sections summarise the results of these surveys. A similar survey has been completed in Croatia by Kunst and Tomljenović (2011).

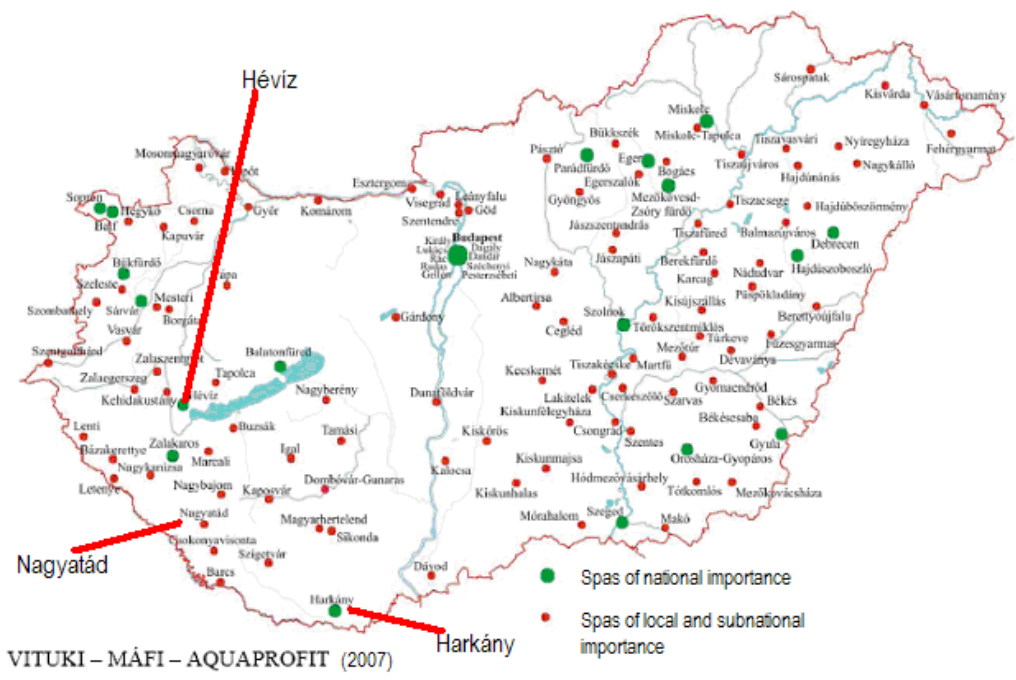

Figure 1: Location of the spa towns where the survey was carried out in Hungary.

Source: Aquaprofit, 2007.

\section{RESULTS}

\section{Survey of Local Residents: Their Attitudes towards the Local Spa}

\section{Survey circumstances, the composition of the resident sample}

In the three spa towns - Hévíz, Harkány, Nagyatád - 100 local residents were questioned in the survey. A random sample was taken. In the sample the proportion of females to males was two thirds to one third, the average age of the respondents was 41 years, and the largest age group was the cohort of 24-40 year olds. The proportion of the older age group (those older than 55 years) was a little higher in Hévíz than in the other two towns. The respondents were relatively well educated, $43 \%$ had completed secondary school, $31 \%$ held higher education degrees. More than half of the respondents were employees, the proportion of managers, leaders and the self-employed entrepreneurs was altogether less than $10 \%$. More than $25 \%$ of them worked in the trade and transport sector, $32 \%$ in the public sector (health care, public 
administration, education), $8 \%$ in the tourism and hospitality sector, while $9.7 \%$ in the service sector. Thus, the proportion of those working in tourism or related sectors is relatively high, although the other sectors, especially services are also represented in high proportions.

\section{Spa visits by local residents}

Characteristics of the spa visits: Altogether $64 \%$ of the local residents visit the local spa, $36 \%$ never do. The local spa for the local residents is an attraction available any time, but one third shows total indifference towards the spa. Half of those who occassionally visit the spa, do this rather infrequently (once or twice a year), they are not really concerned about it. This fact is not really surprising, considering, that except for going with the purpose of recovery from a disease, several visits to the spa during the year would require regularly renewed supply, so that the potential visitors living in the neighbourhood may regularly find some new attractions.

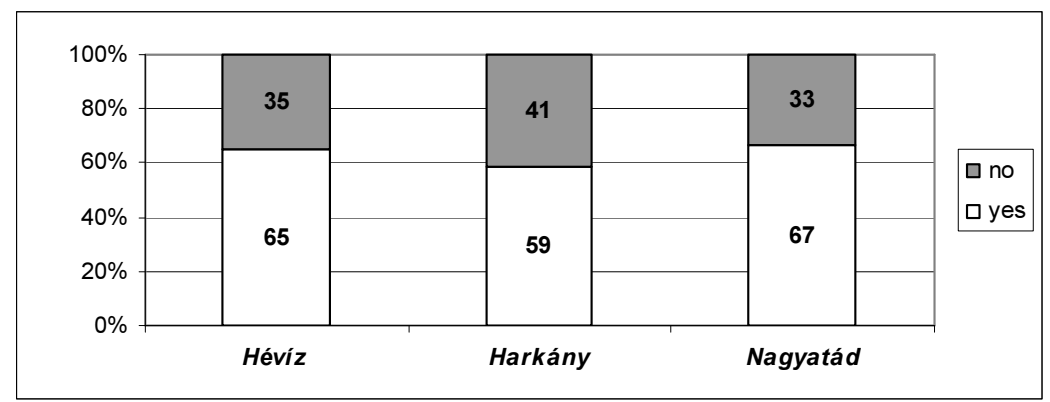

Figure 2: Proportion of spa visitors among the locals 2010. (,do you visit the local spa?")

The purpose of the spa visit: For $28.5 \%$ of the spa visitors bathing is an entertainment, an enjoyment in itself, the main motivation is neither healing nor prevention. Another $11.2 \%$ considers healing and prevention an equally important motivation as bathing for pleasure and entertainment. Somewhat less than one quarter of them $(23.4 \%)$ go for healing or prevention. Altogether, considering the motivations of visiting the spa, the priority of healing or prevention cannot be justified, in spite of the healing capacity of the spa water of which most of the local residents are aware of, bathing has more importance as an entertainment for them. 


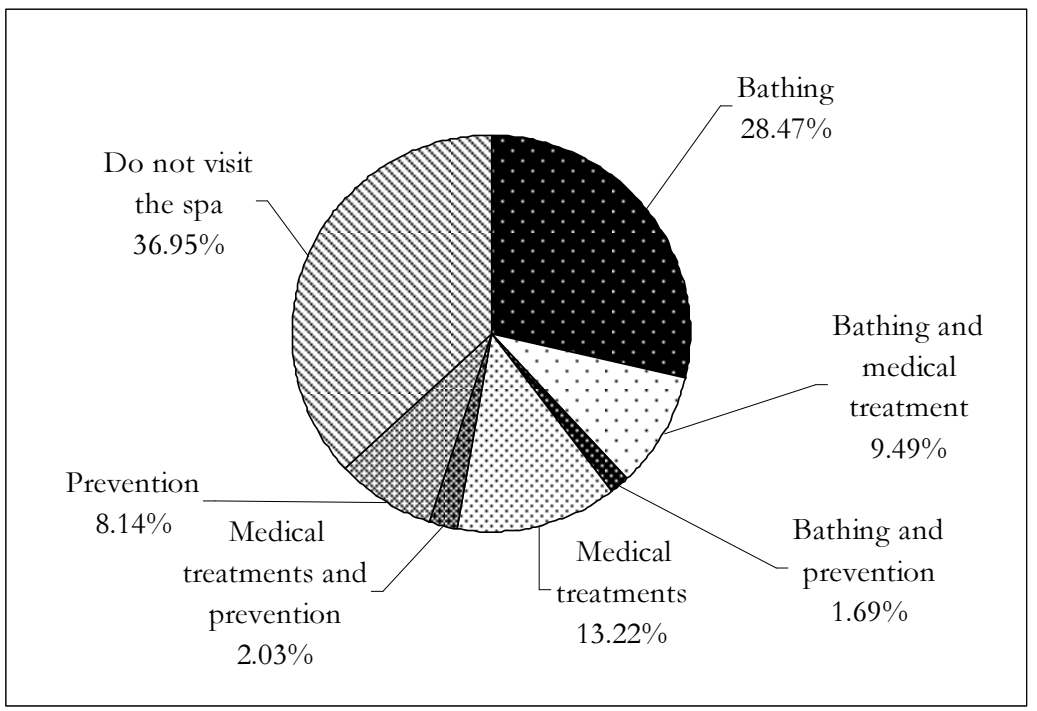

Figure 3. Proportion of local spa visitors by the motivation of the spa visit, 2010.

Level of satisfaction with the services of the spa: The majority of the respondents is satisfied in all of the three towns, but the residents' opinions markedly differ regarding the various services of the spas. In a 1 to 5 scale (where 1 means bad service and 5 excellent service), the medical treatments were given the highest grades, the average grade was between good (4) and excellent (5) for each spa. Bathing facilities in Hévíz and Nagyatád also received good marks, the facilities in Harkány were considerably less satisfactory, of medium quality. The third highest average mark was given for wellness services, although in this respect Nagyatád is considerably less satisfactory than the other two spas, while neither fitness nor food and beverage services reached an average medium qualification, only one of the three spas can get an average of 3 for these aspects. It can be seen then, that there are still many things to do in developing the quality of the spa services, especially regarding the last two components.

The respondents in Hévíz (22\%) complained about the high entrance fees to the spa, and some $(5 \%)$ required longer opening hours, a few respondents also indicated the improvement of hygienic conditions, better supply of food and drinks, extended supply of massage and other services. In Harkány enlargement and modernisation of the pools were missed (by $31 \%$ ), entrance fees were considered too high, food and beverage services were dissatisfactory. 


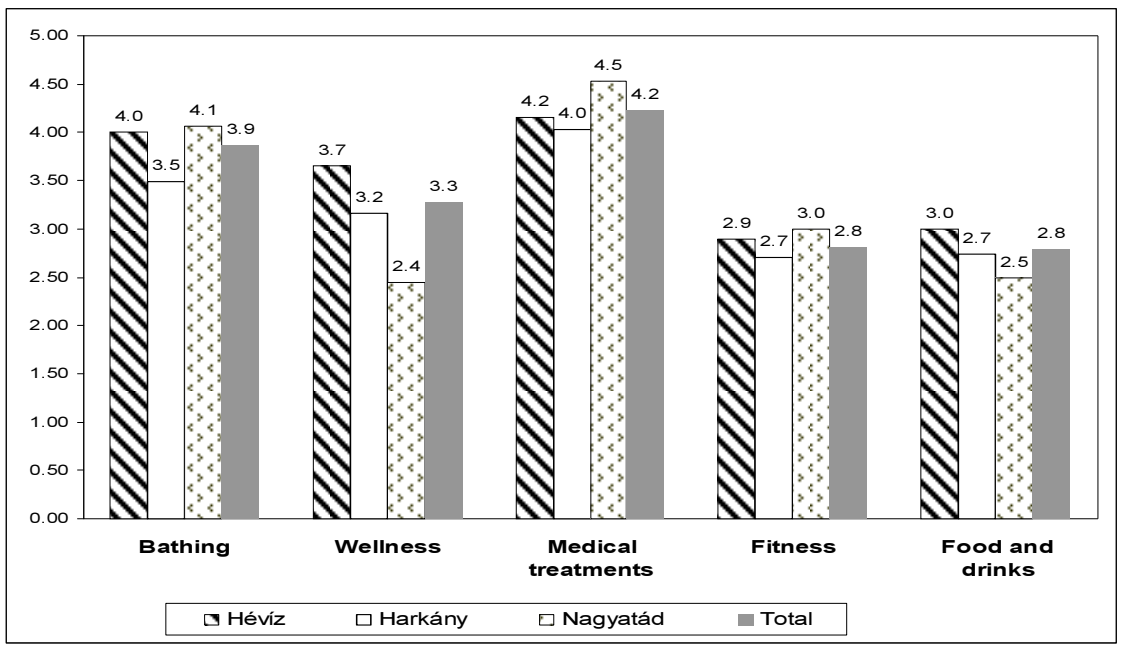

Figure 4. Average level of satisfaction with the various services offered in the spas Note: The assessment was done by a scale of 1to 5, where $1=$ not satisfactory, $5=$ excellent

\section{The role and importance of the spa in the life of the town}

The spa and related accommodation services, as main employers, are important sources of income for the local population. More than half of the respondents in Hévíz and in Harkány have relatives or friends who work in the spa of the town. In Nagyatád, however, health tourism is a less important employer, as $62 \%$ of the respondents do not know anybody among their friends or relations who has a job connected to the spa. Thus, the role of the spa, as an employer, is significantly stronger in Hévíz and Harkány, than in Nagyatád.

Unfortunately, the residents' opinions about the spa, as an employer, are not very positive. Respondents are rather dissatisfied with the working conditions, the income, and the career prospects, although in Hévíz and in Harkány the opinions about hotels are more favourable in this respect. The residents of Nagyatád considered incomes paid by the spa and the hotels average, while in Hévíz, and especially in Harkány, they considered wages and salaries lower than the average. Career prospects seem to be even less satisfactory, than incomes.

Table 1. Average levels of satisfaction about workplace conditions in spas and in hotels, 2010.

\begin{tabular}{|r|c|c|c|c|}
\hline & \multicolumn{2}{|c|}{ Working conditions } & \multirow{2}{*}{ Income } & \multirow{2}{*}{ Career prospects } \\
\cline { 2 - 3 } Hévíz & Hotel & Spa & 1.48 & 1.34 \\
\hline Harkány & 1.96 & 1.48 & 1.33 & 1.29 \\
\hline Nagyatád & 1.47 & 2.09 & 1.72 & 1.31 \\
\hline Number of respondents & 1.91 & 135 & 140 & 140 \\
\hline
\end{tabular}

Note: 1: low, below average; 2: medium, near average; 3: good, above average 


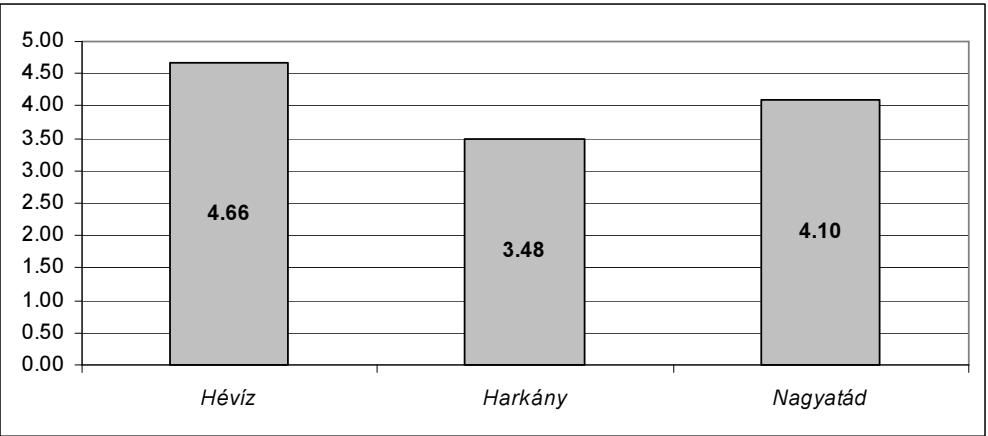

Figure 5. The importance of the spa in the life of the town (2010), averages by a 1 to 5 scale (1: very negative -5 : very positive)

More than half of the respondents considered the role of the spa positive, or very positive in the life of the town, especially in Hévíz and in Nagyatád, while Harkány was considered to be neutral rather than positive. The opinions on the relationship between the town and the spa were cconsidered good in Nagyatád and Hévíz, but more than one third of the respondents in Harkány talked about a bad relationship, and another 12.7\% stated that the spa was a burden on the town, and the proportion of the positive opinions was very low. This definitely indicates an existing conflict between the town of Harkány and its spa.

\section{The impacts of spa developments on the socioeconomic situation in the town}

The spa tourist arrivals have increased in each of the assessed towns, and it had both positive and negative impacts on the residents' quality of life.

Among the positive impacts of growing numbers of tourists most of the inhabitants of Hévíz listed the improved capacity of the town to sustain its population, the second most frequently mentioned advantage was the growth of business turnover, the next one was development in general. Regarding the situation in Harkány, most of the respondents were unable to form an opinion, the next largest group mentioned the growth of business turnover, and it is followed by the group that has felt no positive impacts. In Nagyatád the most frequently mentioned impact was development in general, then the lack of any positive change, and finally the growth in business turnover and the improved capacity of the town to sustain its citizens followed.

The local community generally shows positive feelings towards tourists. The attitude towards tourists was the least positive in Harkány, and most positive in Nagyatád, while the most balanced opinions were received in Hévíz. 
Among the negative impacts caused by tourists the citizens of Hévíz mentioned high prices due to increased demand by tourists, the traffic congestions and rising prices of real estate. In Harkány one third of the respondents denied the existence of any negative impact, some mentioned too high traffic and the tourists disturbing the nightly rest for local citizens as problems. The two thirds of respondents declared in Nagyatád, that no negative impacts were experienced at all, one sixth of the respondents complained about too high car traffic in the town.

\section{The attractions of the town, the competitiveness of the spa in Hungary}

The market success of spa resorts may be improved if, besides the spa, they possess other attractions and opportunities that tourists find exciting. The respondents were usually able to name one or two attractions in their town, of which one was the spa itself. For $47 \%$ of the respondents in Hévíz, and $75.5 \%$ in Harkány the spa was the only attraction of the town, while in Nagyatád the relative majority (43\%) listed four attractions, and another $37 \%$ listed three attractions. It is somewhat surprising, that the residents of Nagyatád, a town really known only in its near vicinity, were able to list more attractions, than those living in the two more famous spa resorts, but probably the listed attractions of Nagyatád are also of less significance. On the other hand, for citizens in Hévíz and in Harkány the spa must be such an unparalleled attraction, that no other local attractions were comparable to it.

The majority of the respondents of each town had experiences of other spas, most of them named 1, 2 or 3 similar spas, which means that they know the supply and services of similar spas elsewhere, thus they have enough experience to compare their spa to other ones.

\section{The experiences about the health tourism supply in Croatia, relations to Croatian tourism}

The last aspect of the survey was whether the local residents know about the supplies of medicinal and wellness tourism in Croatia, whether they have experiences about the endowments of health tourism in Croatia, and of the Croatian - Hungarian tourism connections.

Unfortunately the local residents of Hungarian spa towns seem to have practically no knowledge about health tourism supply in Croatia, nobody in Nagyatád, and only $8 \%$ in Hévíz and $12 \%$ in Harkány were answering this question positively. 
Table 2. Knowledge of the health tourism supply of Croatia, and visits to the Croatian border region, as \% of respondents, 2010.

\begin{tabular}{|r|c|c|c|}
\hline Proportion of Yes answers, $\%$ & Hévíz & Harkány & Nagyatád \\
\hline Do you know the health tourism supply of Croatia? & $8.0 \%$ & $12.0 \%$ & $0.0 \%$ \\
\hline Have you visited the Croatian border region? & $30.0 \%$ & $57.0 \%$ & $45.0 \%$ \\
\hline Number of persons questioned & 100 & 100 & 100 \\
\hline
\end{tabular}

One quarter of those allegedly knowing the health tourism supply in Croatia consider it of good quality, although most of them have experience only about one spa in Croatia. The number of respondents having visited the Croatian border region is the highest $(57 \%)$ in Harkány, followed by $45 \%$ in Nagyatád, while the proportion is lowest $(30 \%)$ among the residents of Hévíz. The frequency of visits to Croatia is higher among residents living closer to the Croatian border, but the motivation is not health tourism. Most of them indicated leisure tourism as the main motivation, other purposes mentioned in Harkány were visiting friends and relatives, the respondents in Nagyatád mentioned visiting friends and relatives, and shopping.

\section{The Visitor Survey: Opinions on the Services Supplied by the Spa Towns}

\section{The characteristics of the visitor sample, the location of the surveys}

A questionnaire-based survey was carried out in three spa towns, asking 102 spa visitors in Hévíz, 101 in Harkány and 100 in Nagyatád. The survey was done mainly in Hungarian, but a few foreign tourists were also randomly selected for the sample.

$41 \%$ of the respondents were male, $59 \%$ female, and due to the random selection this proportion may represent the true gender distribution of spa visitors, that is, generally more women visit spas than men. The most balanced gender distribution was found in Hévíz.

The average age of the spa visitors was 58.6 years, they were a little older in Hévíz and Nagyatád (61 and 62 years respectively), and younger (53 years) in Harkány. In each location the 56-65 and 66-75 age groups were the largest, although in Harkány the proportion of 46-55 year-olds was also high. The average age and the age distribution also show, that spa visitors are mostly older people, although the visitors of the Harkány spa are definitely younger than the two other spas.

In the assessed time period (the end of August, beginning of September) the visitors were mainly domestic tourists. The proportion of foreign visitors was $15.7 \%$ in Hévíz, $10 \%$ in Harkány, and the lowest, only 4\% in Nagyatád. 
In Hévíz the tourists coming from Pest county and Budapest were the largest group (32.6\%), followed by those from Zala and Fejér counties (9.3- 9.3\%, respectively), in Harkány most of the tourists came from Baranya county (45.6\%), followed by Tolna (12.2\%) and Pest including Budapest (10\%), while in Nagyatád the largest groups were those from Somogy (34.4\%) and from Budapest and county Pest (25\%). This means that the spas were most popular with the residents of their own counties, while the tourists from Pest county (including Budapest) were also represented everywhere in high proportions. In Hévíz the proportion of tourists coming from Budapest and Pest County was three times as large as of those coming from the neighbourhood, Zala, which shows the national or even international importance of this spa.

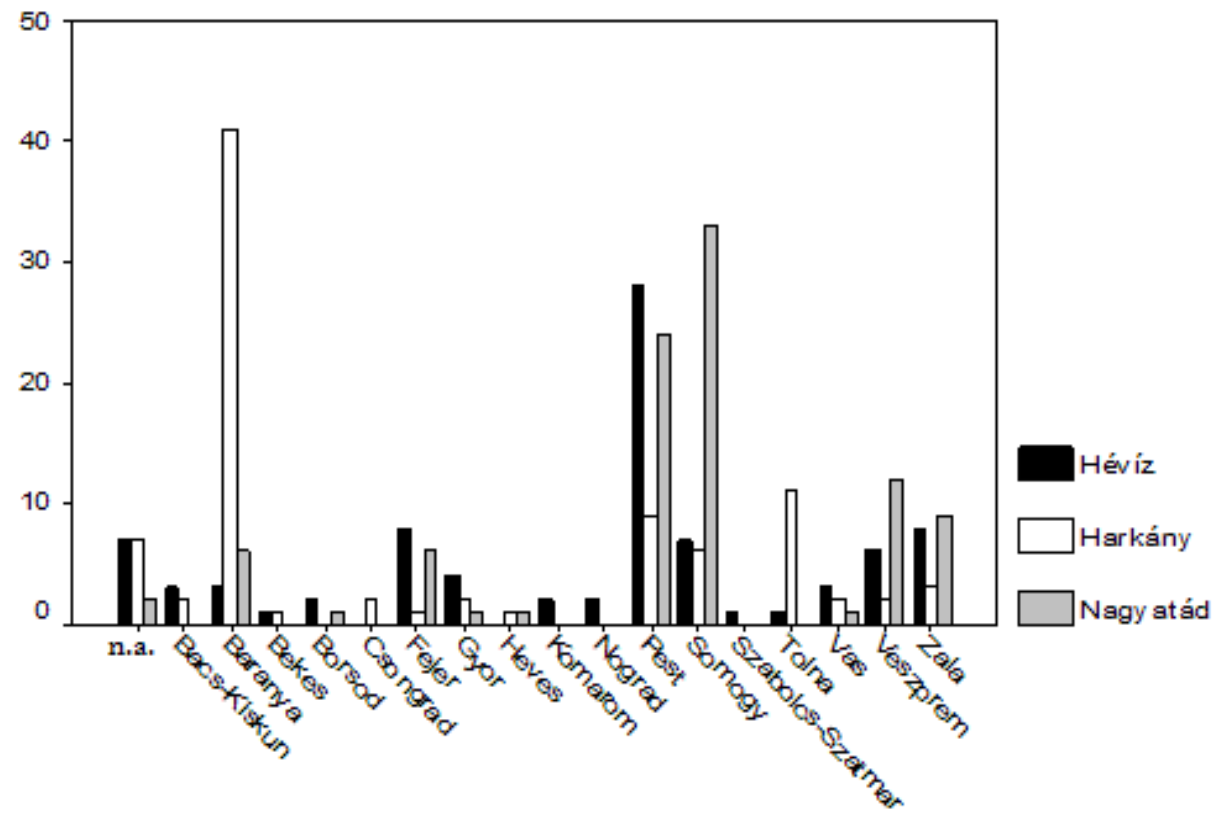

Figure 6. Distribution of domestic tourists by the county of permanent residence (persons) Note: n.a. =no answer was given. The data of county Pest includes Budapest, the capital.

Counties Hajdú-Bihar and Szolnok were not mentioned by any of the respondents

\section{The circumstances of spa visits}

The motivation for spa visits was mainly medical treatment (51.5\%), and another 10.5\% stated this as the secondary motivation besides relaxation or some other purpose. Sport as the main motivation was mentioned by none, and the proportion of those coming with business motivation or with the purpose of visiting an event was also very low. The role of leisure, pleasure, entertainment or relaxation was very high, being the main purpose for $35 \%$. 


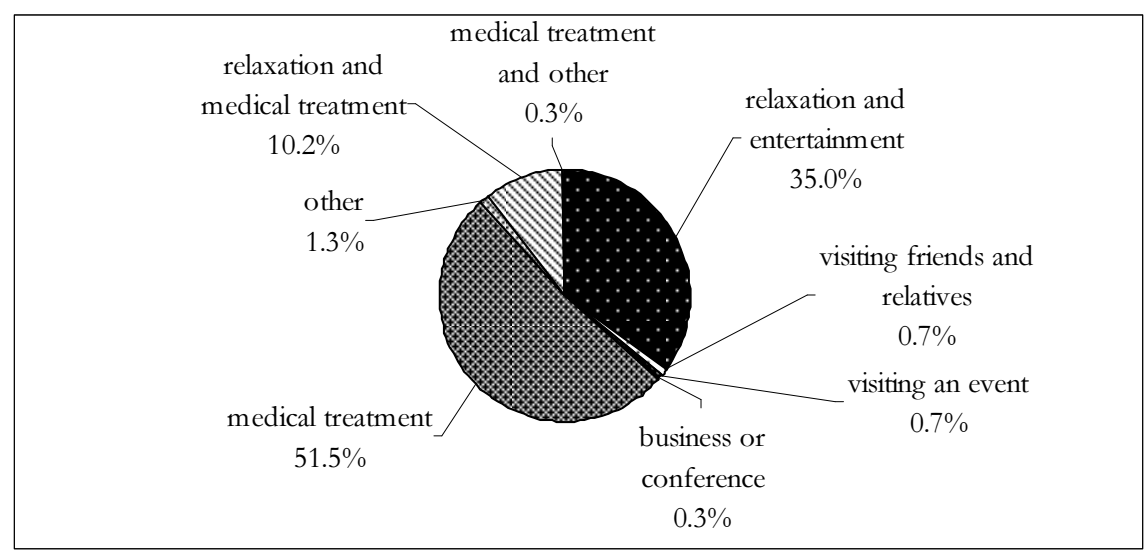

Figure 7. Distribution of spa visitors according to the main motivation of the visit (\%)

Motivations differ by spas, in Hévíz the medical treatment is undoubtedly the main purpose, and it is the purpose for the majority in Harkány, while in Nagyatád the motivation of leisure, entertainment, relaxation and pleasure was more important than that. The majority, $80 \%$ of the spa visitors were well aware of the healing effects of the spas they were visiting.

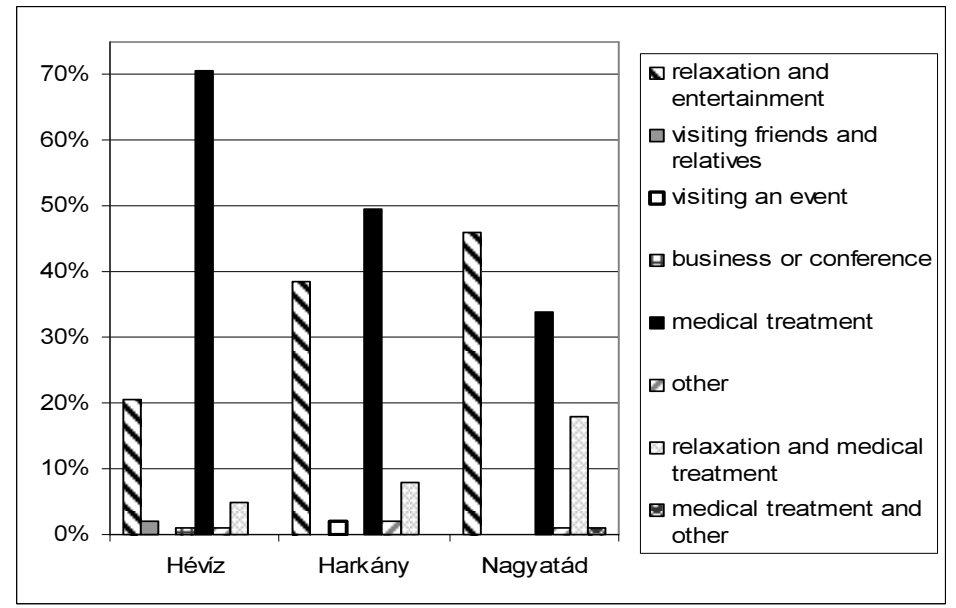

Figure 8. Variations in motivations by spas (The ,other” motivations were not explained by respondents.)

A considerable proportion of spa visitors came only for one day to the spa, living in the neighbourhood and regularly returning, that is, their stay in the town may be considered of several days, without spending a night in the town. The average stay in Hévíz and Harkány (11.4 nights - 11.8 days, and 12.3 nights - 13.8 days, respectively), indicates a regular medical cure with boarding, while these figures are considerably lower in Nagyatád (only 7.6 
days or 4 nights), being only one third of the figure of the other two towns. The differences between the three towns are statistically significant.

Table 2. Average length of stay by spa visitors

\begin{tabular}{|r|c|c|}
\hline Place & Days & Nights \\
\hline & Mean (no. of responses; st. deviation) \\
\hline Hévíz & $11.8(102 ; 6.81)$ & $11.4(90 ; 6.93)$ \\
\hline Harkány & $13.8(100 ; 13.08)$ & $12.3(94 ; 7.26)$ \\
\hline Nagyatád & $7.6(97 ; 7.70)$ & $4.0(91 ; 3.98)$ \\
\hline Total & $11.1(299 ; 9.91)$ & $9.2(275 ; 7.24)$ \\
\hline
\end{tabular}

Three quarters of spa visitors (76.4\%) are returning tourists. The proportion of returning tourists is particularly high in Harkány $(84.7 \%)$, while it is much less in Nagyatád. This suggests that the experiences gained in Nagyatád might be less stimulating for spa visitors to return to that town, Nagyatád is probably less capable of creating a memorable image of its spa, than the other two spa resorts.

Table 3.The proportion of returning visitors in the three spa towns

\begin{tabular}{|r|c|c|c|c|}
\hline Have you been here before? & Hévíz & Harkány & Nagyatád & Total \\
\hline yes & $78.4 \%$ & $84.7 \%$ & $65.2 \%$ & $76.4 \%$ \\
\hline no & $21.6 \%$ & $15.3 \%$ & $34.8 \%$ & $23.6 \%$ \\
\hline Total & $100.0 \%$ & $100.0 \%$ & $100.0 \%$ & $100.0 \%$ \\
\hline
\end{tabular}

\section{The characteristics of the travel decision}

The respondents ranked 13 information sources in making the travel deciavailable in making their travel decision. Rank 1 was given to the most important information source, rank 13 to the least important one. 


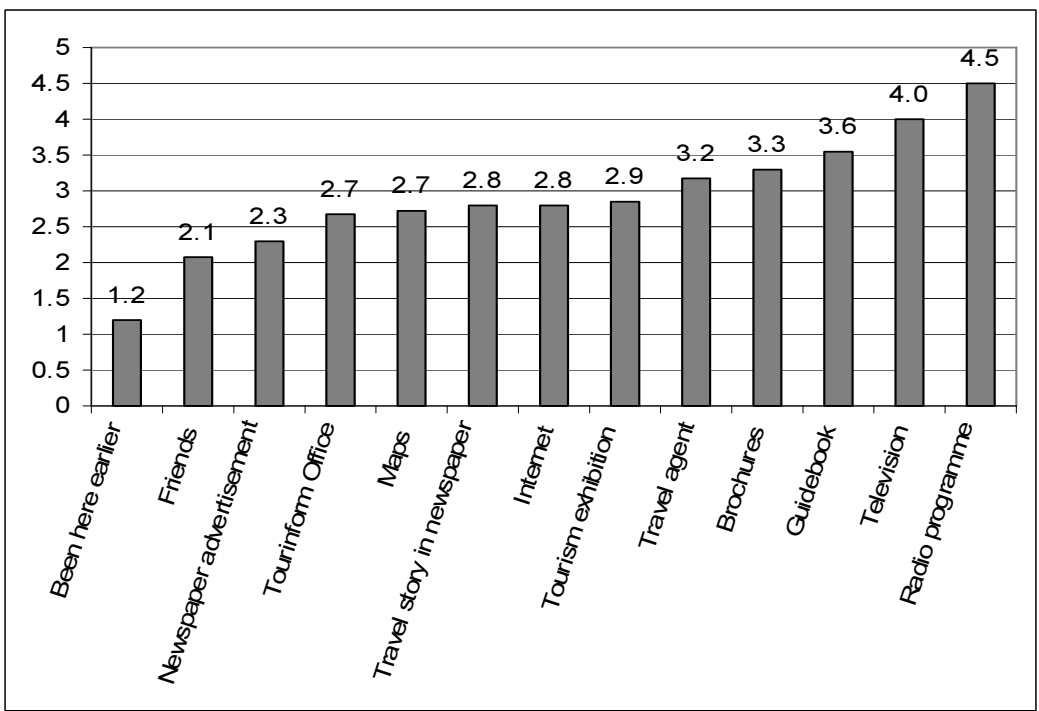

Figure 9. The summary of rankings of information sources by importance

The former personal experience („have been here before”) was the most important information for the decision - followed by the personal recommendations by friends, acquaintances. The printed information resources, Tourinform offices and the internet followed. The least important information sources were said to be the TV and radio broadcasts, these achieved an average 4.0 to 4.5 ranking by importance.

Table 4. The average level of importance of the information sources, by spa towns

\begin{tabular}{|r|c|c|c|c|}
\hline Average ranking & Hévíz & Harkány & Nagyatád & Total \\
\hline Have been here earlier & 1.12 & 1.25 & 1.22 & 1.19 \\
\hline Friends & 2.02 & 2.44 & 1.76 & 2.09 \\
\hline Newspaper advertisements & 2.62 & 2.39 & 1.88 & 2.31 \\
\hline Tourinform Office & 2.64 & 2.71 & 2.67 & 2.67 \\
\hline Maps & 2.64 & 3.00 & 2.00 & 2.72 \\
\hline Travel stories in newspapers & 3.03 & 2.67 & 2.62 & 2.79 \\
\hline Internet & 3.08 & 3.08 & 2.25 & 2.81 \\
\hline Tourism exhibition or fair & 2.86 & - & - & 2.86 \\
\hline Travel agent & 3.50 & 3.00 & 1.67 & 3.17 \\
\hline Brochures & 3.25 & 3.40 & 3.50 & 3.30 \\
\hline Travel guide books & 3.64 & 3.75 & 3.00 & 3.56 \\
\hline TV programmes & 4.06 & 4.06 & 3.33 & 4.00 \\
\hline Radio broadcasts & 4.27 & 4.71 & 4.00 & 4.50 \\
\hline
\end{tabular}

Assessing the three towns separately, clearly the main information source is the experience of an earlier stay everywhere, but while in Hévíz and Harkány this was immediately followed by the role of friends and of newspaper advertisements in the $2^{\text {nd }}$ and $3^{\text {rd }}$ places, the importance of travel agents was ranked before these two information sources in Nagyatád. Printed sources 
of information (guide books, brochures) and the electronic media (radio, TV) were placed at the end of the list in every town. It is somewhat surprising to see that the importance of internet, as a source was considered only medium, it was ranked only around the $6^{\text {th }}-8^{\text {th }}$ places in the list.

For most of the travellers the travel decision is usually made by the traveller himself/herself (51.4\% said so), the second largest group contains those making the travel decision together with their spouse (23.9\%), the next group accepts the decision of his/her spouse about the travel (16\%). In Nagyatád the role of group decisions were also high, due to the more frequent presence of pensioners'clubs and organised groups here.

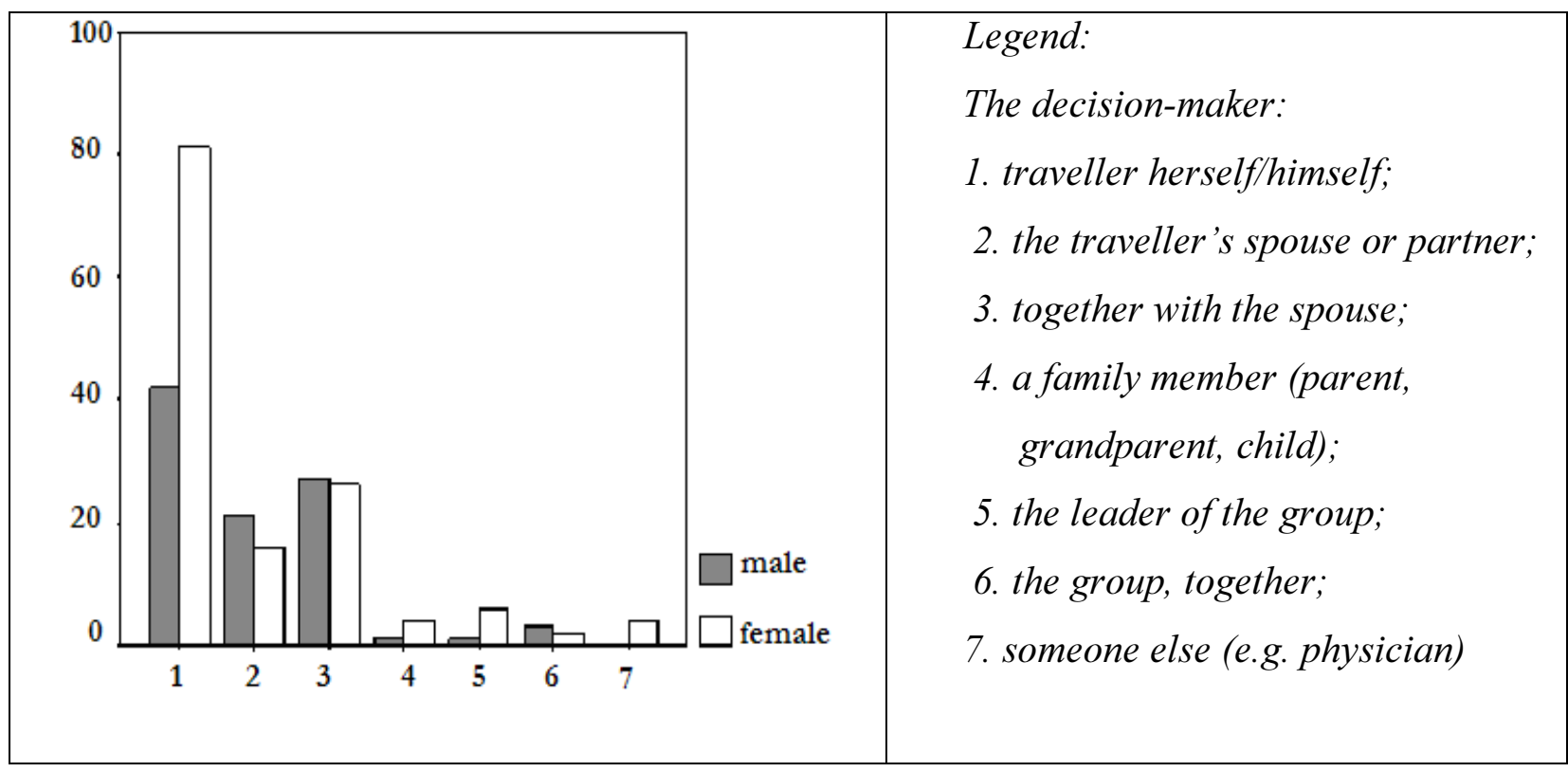

Figure 10. The decision maker in the travel decision, by the gender of the traveller (number of responses in the total sample of 303 persons)

The frequency of independent decisions is higher among female respondents. Even the $22.1 \%$ of male respondents handed over the task of decision-making to his spouse, and another $28.4 \%$ of male respondents make a joint decision together with his spouse. This means, that for $50.5 \%$ of the male spa visitors the role of women is crucial in making the decision, while $77.0 \%$ of the female respondents make their own decisions, or form a joint decision together with their spouses. This information may be useful when planning marketing campaigns, as it seems reasonable to target the marketing message at the female decision makers. It should be noted that among those who had had earlier personal experience about the spa, the proportion of decisions made by the traveller is much higher $(55.7 \%)$ than for those who had no such experience before $(32.1 \%)$. 
The average size of the group travelling to the spa was found to be 3.51 persons on average. The most frequent company was of 2 persons, $38.9 \%$ of the respondents travelled like that. The proportion of single travellers was only slightly lower, $37.6 \%$. The frequency of 3-person groups was $8.6 \%$, and $7.9 \%$ of the respondents travelled with a larger group than that.

In Hévíz the proportion of respondents travelling in two was far the highest $(47.1 \%)$, and $42.1 \%$ travelled alone, which made up the vast majority of respondents. In Harkány the lonely travellers were the largest group (42.6\%), in similar proportions as in Hévíz, the proportion of those travelling with one more person was less than that $(35.6 \%)$, but here again these two groups were the most important. In Nagyatád, besides the 2-person groups (34\%) and lonely travellers $(28 \%)$ the proportion of respondents travelling with a group larger than 6 members was remarkable $(22 \%)$.

The majority of the spa visitors came to the spa on their own, in Harkány (96\%) and in Hévíz (93\%) nearly everybody travelled like this. In Nagyatád, however, organised trips make of about one third of the total visitor arrivals. The most often used mode of transport is the passenger car $(56.1 \%)$, followed by coach $(38.3 \%)$, travels by other modes of transport were neglectable. Coach travel is mainly typical for organised journeys $(81.8 \%)$, although nearly one third of the individual travellers also took a coach $(30.8 \%)$.

\section{Services utilised and level of satisfaction}

The choice of accommodation shows a rather heterogenous pattern. Most of the spa visitors $(30.5 \%)$ stayed in hotels, but a high proportion of visitors $(23.8 \%)$ did not take any accommodation. In Nagyatád most of the respondents (51\%) stayed in hotels, the second most popular accommodation (33\%) was the campsite; in Hévíz and Harkány most of the visitors took no accommodation at all, followed by those staying in hotels, private accommodation, campsite and holiday resort houses. A typical feature in Hévíz was the more than $10 \%$ frequency of a hospital or a sanatorium as place of accommodaton. 


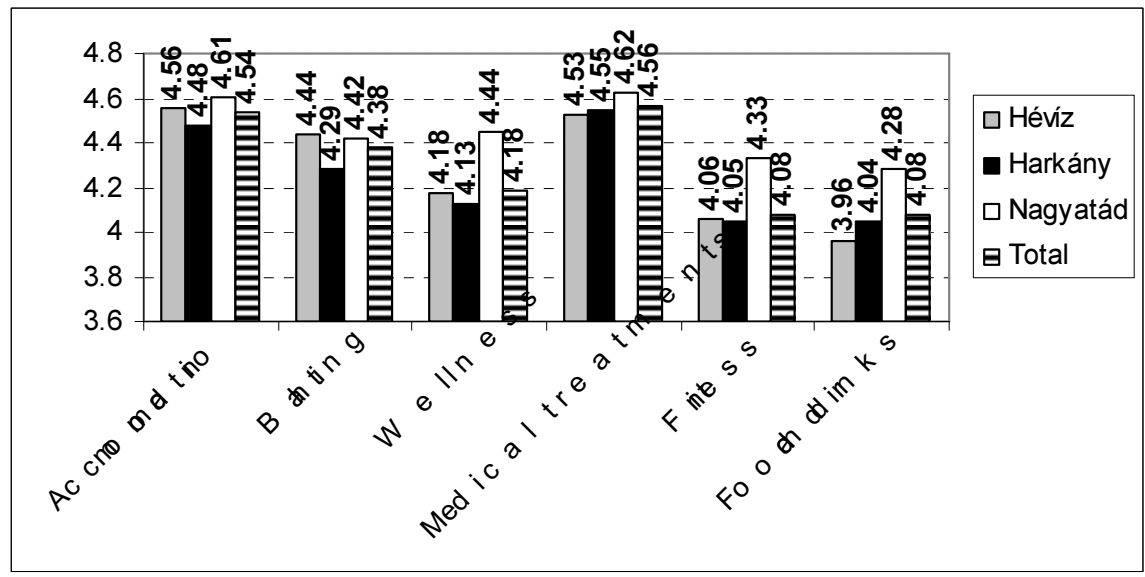

Figure 11. The average rating of spa services, scale of 1 to 5

Assessing the level of satisfaction with the services provided by the spa, on a scale of 1 to 5 (1: very dissatisfied, 5: very satisfied, 6: no answer), the spa visitors were found to be most satisfied with accommodation, bathing and medical treatments, and least satisfied with fitness and food and beverage services. However, in Nagyatád the two latter aspects also received an average rating similar to the other aspects, while in the two other spas these were valued somewhat less. Most of the visitors were satisfied or very satisfied with accommodation (the average rating was 4.54 , while the ratings by towns varied between 4.47 and 4.60 ). The proportion of accommodations rated as excellent was high, above $50 \%$, in every town. Regarding food the respondents of Hévíz were the least satisfied, their average rating was 3.96 , the only rating below 4.0 .

Only a few respondents listed anything they had missed in the spas. A few mentioned fun pools of medicinal water, improved sports facilities, children's playgrounds, handrails for the pools, air conditioning, fitness room, separated bathing facilities, sauna, beach chairs, poker room, and bank branch office.

Assessing the value for price of the spas the bathing and wellness services were considered rather expensive in Hévíz and in Harkány. In Hévíz the medical treatments, fitness and food were considered correct value for the price, in the other two spas the prices were considered good for the value. Regarding every aspect Nagyatád was given the best rating of the three spas by the spa visitors. The greatest difference between Hévíz and Harkány was found in the valuation of medical treatments, and except for wellness all the services of Hévíz were rated lower than those of the other two spas. 
Assessing the daily spending by spa visitors the largest group of them (46\%) spent a sum between 1000-5000 HUF (approximately 3.6-18 EURO in 2010). The second largest group of visitors spent less than 1000 HUF (39.6\%). In Nagyatád most of the visitors spent less than 1000 HUF a day (49\%). Estimating the daily spending by the mean of the spending categories, the average daily spending per person can also be estimated. In this respect the visitors of Harkány made the largest daily spending of $3220 \mathrm{HUF} /$ person, followed by Hévíz (2830 HUF), by Nagyatád (1893 HUF) with a much lower spending value. The daily cost of accommodation varies between 9200 and 2200 HUF, a rather wide range, the highest values were found in Hévíz, the lowest in Harkány, although only 1000 HUF lower than that of Nagyatád.

Table 5. Estimated average daily spending and average accommodation cost

\begin{tabular}{|r|c|c|c|c|c|c|}
\hline & \multicolumn{3}{|c|}{$\begin{array}{c}\text { Mean daily spending } \\
\text { (HUF/person/day) }\end{array}$} & \multicolumn{3}{c|}{$\begin{array}{c}\text { Mean accommodation cost } \\
\text { (HUF/prson/night) }\end{array}$} \\
\hline Location & Mean & No. & Std. Dev. & Mean & No. & Std. Dev. \\
\hline Hévíz & 2830 & 100 & 2682.0 & 9168 & 84 & 29184.0 \\
\hline Harkány & 3220 & 100 & 2856.3 & 2233 & 86 & 3869.2 \\
\hline Nagyatád & 1893 & 98 & 1767.8 & 3324 & 93 & 2948.5 \\
\hline Total & $\mathbf{2 6 5 3}$ & $\mathbf{2 9 8}$ & $\mathbf{2 5 3 9 . 1}$ & $\mathbf{4 8 3 4}$ & $\mathbf{2 6 3}$ & $\mathbf{1 6 9 3 4 . 6}$ \\
\hline
\end{tabular}

\section{The evaluation of the town attractions}

The spa visitors were asked to evaluate the spa town in 11 aspects, by a 1 to 5 Likert scale ( $1=$ very negative; $2=$ negative; $3=$ neutral; $4=$ positive; $5=$ very positive): the atmosphere of the town, information for tourists; town view (built environment); natural environment; infrastructure; traffic and transport; events and sights; shopping opportunities; parking conditions; water quality; cleanliness and hygiene.

Except for parking, and in Hévíz the information for tourists, all the other aspects were valued as 4 or 5, that is, positive or very positive. In Nagyatád, parking was not valued lower, than the other aspects, either, which is probably due the lower number of tourists, less intensive traffic, and altogether to the character of a small town. The best values were given to the quality of the environment, the water quality, and the cleanliness and hygiene aspects. The assessments differed by town at statistically significant levels (of 5\% error probability), except for water quality; this aspect received very similar positive values in each town.

Considering average values Nagyatád received the best average evaluation (of 4.57 on average), and while assessing the aspects separately the lowest average value was still above 4 
(traffic and transport, 4.34). The second best town was Hévíz, with an average value of 4.23, although the difference between the lowest and the highest average by aspect is nearly 1.5 points (water quality: 4.78 and parking: 3.30), and there are altogether 3 aspects with averages below 4.0 (besides parking the traffic/transportation and the infomation for tourists). Harkány was only a little worse than Hévíz, with the average value 4.21, but here every aspect was valued above 4.0 on average, except parking (3.64).

The two most positive factors were cleanliness and water quality, and traffic and transport and parking were the weakest all the three towns. It is somewhat surprising, that the least famous Nagyatád received the best values among the three towns for information, town view, infrastructure, transport, events, shopping, parking and cleanliness alike, that is, for 8 of the 11 aspects.

Spa visitors had experience from other spas, most of them $(78.5 \%, 238$ respondents) were able to name at least one other spa visited. The most experienced respondents were found in Nagyatád, and those of Hévíz the least experienced regarding other spas. The largest proportion of respondents named Zalakaros, followed by Hévíz, then Hajdúszoboszló, Harkány and Gyula.

\section{DISCUSSION}

The following table summarises the survey findings of residents' opinions in spa towns: 
Table 6. Summary of residents' opinions in three spa towns

\begin{tabular}{|c|c|c|c|}
\hline Aspects & Hévíz & Harkány & Nagyatád \\
\hline $\begin{array}{l}\text { Characteristics of the } \\
\text { resident sample }\end{array}$ & $\begin{array}{l}1 / 3 \text { men, } 2 / 3 \text { women, } \\
\text { many with degree, } 41 \text { ys } \\
\text { old on average, most are } \\
\text { employees in the } \\
\text { services sector }\end{array}$ & $\begin{array}{l}40 \% \text { men, } 60 \% \\
\text { women, few with } \\
\text { degree, } 41 \text { ys old on } \\
\text { average, most are } \\
\text { employees in the } \\
\text { services sector }\end{array}$ & $\begin{array}{l}1 / 4 \text { men, } 3 / 4 \text { women, } \\
\text { many with degree, } 41 \\
\text { ys old on average, } \\
\text { most employees in the } \\
\text { services sector }\end{array}$ \\
\hline Habits of spa visits & $\begin{array}{l}\text { Two thirds go, more for } \\
\text { pleasure than healing }\end{array}$ & $\begin{array}{l}\text { Two thirds go, more for } \\
\text { pleasure than healing }\end{array}$ & $\begin{array}{l}60 \% \text { go, more for } \\
\text { pleasure than healing }\end{array}$ \\
\hline \multicolumn{4}{|c|}{ Level of satisfaction about spa services: } \\
\hline - bathing & Good & Medium & Good \\
\hline - medical treatments & Good & Good & Good \\
\hline - wellness services & Good & Good & Medium \\
\hline - fitness services & Hardly medium & Hardly medium & Medium \\
\hline - food and drinks & Medium & Hardly medium & Hardly medium \\
\hline $\begin{array}{l}\text { Improvements needed in } \\
\text { the spa }\end{array}$ & $\begin{array}{c}\text { Decrease high entrance } \\
\text { fee, longer opening } \\
\text { hours }\end{array}$ & $\begin{array}{l}\text { Enlarge pools, decrease } \\
\text { high entrance fee }\end{array}$ & None \\
\hline $\begin{array}{l}\text { The role of the spa and } \\
\text { hotels as employers }\end{array}$ & Very important & Very important & Not very important \\
\hline $\begin{array}{l}\text { The working conditions } \\
\text { in the spa and in hotels }\end{array}$ & Hotels are better than spa & $\begin{array}{l}\text { Hotels are better than } \\
\text { spa }\end{array}$ & $\begin{array}{c}\text { Hotels are worse than } \\
\text { spa }\end{array}$ \\
\hline $\begin{array}{l}\text { Income and career } \\
\text { situation }\end{array}$ & Below average & Below average & About average \\
\hline $\begin{array}{l}\text { The role of the spa in the } \\
\text { life of the town }\end{array}$ & $\begin{array}{l}\text { Very important, good } \\
\text { connections }\end{array}$ & $\begin{array}{l}\text { Not so important, not } \\
\text { very good connections }\end{array}$ & $\begin{array}{l}\text { Very important, good } \\
\text { connections }\end{array}$ \\
\hline $\begin{array}{l}\text { Positive impacts of } \\
\text { tourism in the town }\end{array}$ & $\begin{array}{l}\text { Capacity to sustain, } \\
\text { business turnover, } \\
\text { progress in general }\end{array}$ & $\begin{array}{c}\text { Business turnover } \\
\text { growing, or no positive } \\
\text { impact }\end{array}$ & $\begin{array}{c}\text { Progress in general, or } \\
\text { no positive impact }\end{array}$ \\
\hline $\begin{array}{l}\text { Negative impacts of } \\
\text { tourism in the town }\end{array}$ & $\begin{array}{c}\text { Parking problems, } \\
\text { overcrowding, high } \\
\text { prices }\end{array}$ & $\begin{array}{l}\text { Not enough tourists, } \\
\text { too high prices }\end{array}$ & No negative impact \\
\hline Attitude towards tourists & Positive & Positive or neutral & Very positive \\
\hline $\begin{array}{l}\text { Attractions of the town, } \\
\text { the rank of the spa among } \\
\text { them }\end{array}$ & $\begin{array}{c}\text { The spa is the main } \\
\text { attraction }\end{array}$ & $\begin{array}{c}\text { The spa is the main } \\
\text { attraction }\end{array}$ & $\begin{array}{l}\text { The spa is important, } \\
\text { but other attractions }\end{array}$ \\
\hline $\begin{array}{l}\text { Relations to health } \\
\text { tourism supply in Croatia }\end{array}$ & Little or no experience & Little experience & No experience \\
\hline $\begin{array}{l}\text { Motivation of travels to } \\
\text { Croatia }\end{array}$ & Leisure tourism & $\begin{array}{l}\text { Visit friends/relatives, } \\
\text { leisure tourism }\end{array}$ & $\begin{array}{c}\text { Visit friends/relatives, } \\
\text { shopping, leisure } \\
\text { tourism }\end{array}$ \\
\hline $\begin{array}{l}\text { Opinion about Croatian } \\
\text { tourism }\end{array}$ & No knowledge & Mostly positive opinion & $\begin{array}{l}\text { Little knowledge, } \\
\text { positive opinion }\end{array}$ \\
\hline
\end{tabular}

Generally local residents showed a positive attitude towards the spa as an attraction for leisure and pleasure, appreciating bathing more than healing. They are rather satisfied with the spa services, but food and drinks, and fitness services are considered of lower quality. In Hévíz the spa prices are considered too high for value, and this is really the most expensive spa of 
the three. The local residents of Harkány complained about technical improvements needed, while the citizens of the small town Nagyatád were very satisfied with their spa.

In Nagyatád the spa was considered less important in the socioeconomic life of the town than in the other two famous spa towns. However, in Hévíz and Nagyatád the incomes earned and carreer prospects in the spa and related hotels were considered worse than the town average. The relationship between town leadership and spa were considered rather negative in Harkány. Local residents have positive feelings towards tourists, but the positive impacts of tourism are felt only in Hévíz, although here parking problems and high prices were felt as negative impacts. In Harkány the low number of tourists and the high prices were the main negative aspects, while in Nagyatád no negative impacts of tourism were felt.

It is worth mentioning that the local residents of the three spa towns had hardly any knowledge about the health tourism supply of Croatia, and if they go to Croatia it is usually for visiting friends and relatives and for leisure (to the sea).

The following table briefly summarises the profile of the typical spa visitor, according to the aspects of the questionnaire. 
Table 7. The profile of the typical spa visitor in the three spa towns

\begin{tabular}{|c|c|c|c|}
\hline & Héviz & Harkány & Nagyatád \\
\hline Gender, age & Female/ male, 61 ys & More females, 62 ys & Female, 58 ys \\
\hline Permanent residence & $\begin{array}{l}\text { Budapest+Pest (Zala, } \\
\text { Fejér) }\end{array}$ & $\begin{array}{l}\text { County Baranya ( } \\
\text { Tolna, Pest, Budapest) }\end{array}$ & $\begin{array}{l}\text { County Somogy, Pest } \\
\text { and Budapest }\end{array}$ \\
\hline Motivation & Medical treatment & Medical treatment & Leisure \\
\hline $\begin{array}{l}\text { Knowledge about healing } \\
\text { character of the water }\end{array}$ & Knows well & Knows well & Mostly knows \\
\hline $\begin{array}{l}\text { Background for the travel } \\
\text { decision }\end{array}$ & Personal experience & Personal experience & $\begin{array}{l}\text { Personal experience } \\
\text { and travel agent }\end{array}$ \\
\hline $\begin{array}{l}\begin{array}{l}\text { Length of stay (nights- } \\
\text { days) }\end{array} \\
\end{array}$ & $11-12$ & $12-13$ & $4-8$ \\
\hline Returning visitor? & Yes & Yes & Yes \\
\hline $\begin{array}{l}\text { Type of travel, decision } \\
\text { maker }\end{array}$ & $\begin{array}{l}\text { Individual traveller } \\
\text { by own decision or } \\
\text { together with spouse }\end{array}$ & $\begin{array}{l}\text { Individual traveller by } \\
\text { own decision or } \\
\text { together with spouse }\end{array}$ & $\begin{array}{l}\text { Individual traveller, } \\
\text { own decision or with } \\
\text { spouse; or organised } \\
\text { trip, group decision }\end{array}$ \\
\hline Size of travelling company & $1-2$ pers & $1-2$ persons & 7 (or 1-2) persons \\
\hline Mode of travel & Car & Car & Coach or car \\
\hline Accommodation & $\begin{array}{l}\text { el / private } \\
\text { lion }\end{array}$ & $\begin{array}{l}\text { None /hotel / private } \\
\text { accommodion }\end{array}$ & Hotel / campsite \\
\hline $\begin{array}{l}\text { Satisfaction } \\
\text { accommodation }\end{array}$ & (Very) satisfied & (Very) satisfied & (Ver \\
\hline $\begin{array}{l}\text { Satisfaction with spa } \\
\text { services }\end{array}$ & $\begin{array}{l}\text { Satisfied with bathing } \\
\text { and treatments, less } \\
\text { with fitness and food }\end{array}$ & $\begin{array}{l}\text { Satisfied with bathing } \\
\text { and treatments, less } \\
\text { with fitness and food }\end{array}$ & $\begin{array}{l}\text { (Very) satisfied with } \\
\text { everything }\end{array}$ \\
\hline $\begin{array}{l}\text { Assessment of value for } \\
\text { money }\end{array}$ & $\begin{array}{l}\text { Bathing and wellness } \\
\text { expensive, treatments } \\
\text { and wellness correct } \\
\end{array}$ & $\begin{array}{l}\text { Bathing and wellness } \\
\text { expensive, other } \\
\text { services favourable }\end{array}$ & $\begin{array}{l}\text { All services } \\
\text { favourable prices }\end{array}$ \\
\hline $\begin{array}{l}\text { Expected and experienced } \\
\text { prices }\end{array}$ & Correct & Correct & Favourable \\
\hline Daily spending (HUF/day) & $2830 \mathrm{HUF} /$ person & $3220 \mathrm{HUF} /$ person & $1890 \mathrm{HUF} /$ person \\
\hline $\begin{array}{l}\text { Price of accommodation } \\
\text { day }\end{array}$ & $9200 \mathrm{HUF} /$ person & $2200 \mathrm{HUF} /$ person & $3300 \mathrm{HUF} /$ person \\
\hline $\begin{array}{l}\text { Image of the spa town by } \\
\text { visitors }\end{array}$ & $\begin{array}{l}\text { Parking and } \\
\text { information medium, } \\
\text { others positive }\end{array}$ & $\begin{array}{l}\text { Parking medium, } \\
\text { others positive }\end{array}$ & $\begin{array}{l}\text { Positive in every } \\
\text { aspect }\end{array}$ \\
\hline Number of spas visited & 2.35 & 2.57 & 2.79 \\
\hline
\end{tabular}

The most marked differences in the visitors of the three spas are with respect to age, length of stay, the motivation and purpose of visit, the accommodation taken, the daily spending and cost of accommodation, and the opinions on the spa services. While the tipical visitor to Hévíz is elderly, near the pensioner age, and stays for about two weeks for a medical treatment, paying a high price for the accommodation, who is not completely satisfied with the services offered by the spa and by the town, the typical visitor to Harkány is rather similar, but spends much less on accommodation. The visitors to Nagyatád, however, are 3-4 years younger, spend only a little, often comes with a group in an organised tour, stays about 
half as long as the visitors of the other two spas, and is usually completely satisfied with the services of the spa and the town. Those visiting Nagyatád, have already been to several other spas, being experienced spa visitors. Nagyatád, unfortunately, seems to have difficulties in converting the favourable opinions into revenues, the visitors stay only for a short time, and spend very little, and the town is obviously capable to attract much less tourists than the other two - regionally or internationally renowned - spa resorts.

\section{CONCLUSION}

The objective of the present research was to assess the competitiveness of health tourism in the Croatian-Hungarian border region, in three counties of the Croatian, and three counties of the Hungarian side. The present paper described the findings of two questionnaire-based surveys, one among the local residents of three spa towns (Hévíz, Harkány and Nagyatád), the other among the spa visitors of these spas.

Local residents were asked about their relationship to the local spa, the impacts of the spa on the economy of the town, and the quality of the facilities and suggested improvements. Spa visitors, tourists were asked about their opinion and level of satisfaction with spa services, their travel decision and their travel behaviour (duration, spending).

The opinions of the local residents were similar in many aspects for all the three spa towns. The most marked difference is found in the fact, that the small, relatively little known spa of Nagyatád was considered a very positive, although economically not too important component of the town. Local citizens enjoy it as a leisure service, and being small and little know outside the neighbourhood, it does not generate excessive traffic, nor parking problems, but its income generating capacities are also low. The other two towns - Hévíz and Harkány are regionally and internationally known spa resorts, where spa tourism is expected to be a major income resource for the towns and their citizens. Here the citizens were more critical about the services of the spa and the impacts of tourism on their town. As the spa was considered to be the main attraction and a very important source of income for the population, the citizens were more aware of the negative aspects, including high entrance fees and high prices, but low incomes and weak carreer prospects for labour.

Considering the results of the tourist survey it is worth noting that tourists had generally better opinions about the spa services than local residents. The two famous spas - Hévíz and Harkány - are visited for health purposes, and mainly by elderly people, while the small local spa of Nagyatád is visited by younger people and mainly for leisure and pleasure. This is reflected by the duration and spending as well - although tourists coming for medical 
purposes do not generally spend much time and money in the town, as they are accommodated in a hotel or a sanatorium. Accessibility may be a problem: the spas may be visited by car, but occassionally by coach. However, regional and international access is limited by the not too well developed public transport system. Travel decisions are usually based on personal information (the proportion of returning visitors was high), and travel agents and printed brochures seem to be inefficient marketing resources. It is worth noting that the travel decision is most often made by women, so marketing messages may be focused on them. Another important aspect is that besides the immediate neighbourhood of the spa towns, a large proportion of tourists come from the capital, Budapest, which is again an important consideration for targeting the marketing message.

Tourists and local residents considered spa prices somewhat high, and food and beverages, and fitness services not satisfactory. Both tourists and locals found parking to be a problem, and tourists in Hévíz also complained about the availability of information about the town. Nagyatád, a relatively less known spa, was able to make an overall positive impression on tourists and locals, but its marketing activities are not sufficient to create a stable base of returning tourists. Its financial viability is based on the local citizens and those living in the near vicinity of the town. Hévíz seems to maintain its international attractiveness, while Harkány is struggling with the impacts of conflict between the town and the spa leadership. The nearby Croatian border region may be an important market for all the three spa towns, but currently the knowledge of the cross-border region is little known, and the opportunities are not utilised.

\section{LITERATURE}

1. Aquaprofit Rt. (2007): Országos egészségturizmus fejlesztési stratégia. Budapest. (In Hungarian)

2. Kovács, E.; Bacsi, Zs.; Lőke, Zs. (eds, 2011a): The Role of Health Tourism in Improving the Competitiveness of the Croatian-Hungarian Border Region. Balatoni Integrációs Közhasznú Nonprofit Kft, Siófok (Hungary)

3. Kovács, E.; Bacsi, Zs.; Lőke, Zs. (2011b): Healing - Pleasure - Competitiveness: Empirical Assessment of the Spa Settlements in Baranya, Somogy and Zala counties. In: Kovács, E. ; Bacsi, Zs.; Lőke, Zs. (eds, 2011): The Role of Health Tourism in Improving the Competitiveness of the Croatian-Hungarian Border Region (pp. 39-76). Balatoni Integrációs Közhasznú Nonprofit Kft, Siófok (Hungary) 
4. Kunst, I.; Tomljenović, R. (2011): The role of health tourism in improving the competitiveness of rural areas in the Republic of Croatia. In: Kovács, E. ; Bacsi, Zs.; Lőke, Zs. (eds, 2011): The Role of Health Tourism in Improving the Competitiveness of the Croatian-Hungarian Border Region (pp. 77-118). Balatoni Integrációs Közhasznú Nonprofit Kft, Siófok (Hungary)

5. MTZrt (2002-2009): Turizmus Magyarországon 2002.-2009. <www.itthon.hu> (in Hungarian)

6. VITUKI - MÁFI - AQUAPROFIT (2007): Magyarország termál- és gyógyfürdői térkép. In: Aquaprofit Rt. (2007): Országos egészségturizmus fejlesztési stratégia. Budapest (in Hungarian)

7. WTTC (2002): A turizmus hozzájárulása a legfontosabb gazdasági mutatókhoz 1998ban és 2002-ben. In: MTRt (2002): Turizmus Magyarországon 1990-2002. www.itthon.hu (in Hungarian) 